Bangladesh J. Plant Taxon. 22(2): 77-81, 2015 (December)

\title{
TYPIFICATION OF TEN SPECIES OF LITSEA LAM. (LAURACEAE) ENDEMIC TO INDIA
}

\author{
RAJEEV KUMAR SINGH, ARTI GARG ${ }^{1}$ AND PARAMJIT SINGH ${ }^{2}$ \\ Botanical Survey of India (BSI), Central Regional Centre (CRC), 10-Chatham Lines, \\ Allahabad 211 002, Uttar Pradesh, India
}

Keywords: Lauraceae; Litsea; Type; India.

\begin{abstract}
This paper deals with the lectotypification of eight binomials of seven recognized species of Litsea Lam. endemic to India, namely Litsea assamica (Meisn.) Hook. f., L. coriacea (B. Heyne ex Nees) Hook. f., L. membranifolia Hook. f., L. oleoides (Meisn.) Hook. f., L. stocksii (Meisn.) Hook. f., L. venulosa (Meisn.) Hook. f., and L. wightiana (Nees) Hook. f. Types of three other endemic species, viz. L. beddomei Hook. f., $L$. mishmiensis Hook. f. and L. oreophila Hook. f. are also specified.
\end{abstract}

\section{Introduction}

The family Lauraceae Juss. comprises 52 genera with about 2,550 species, distributed mainly in the tropical and warm regions of southeastern Asia and Brazil (Mabberley, 2008; Bhuinya et al., 2010). The genus Litsea Lam. consists of more than 300 species worldwide, especially in tropical Asia and Australia (Mabberley, 2008; Bhuinya et al., 2010). In India, there are 45 species, occurring in moist deciduous, semi-evergreen, and evergreen forests at 200-3,650 m elevation, with 18 species endemic to different states (Bhuinya et al., 2010; Singh, 2015). As part of the revisionary studies of Litsea in India, we realized the necessity for typification of some endemic species; hence, here we lectotypified eight binomials of seven species of the genus. While designating lectotypes, we followed the guidelines of Art. 9.2 of the Melbourne Code (McNeill et al., 2012). Specification of holotype for other three endemic species was done as no holotype was cited in their protologues.

\section{Taxonomy}

1. Litsea assamica (Meisn.) Hook. f., Fl. Brit. India 5: 161 (1886). Tetranthera rangoonensis Meisn. var. assamica Meisn. in De Candolle, Prodr. 15(1): 188 (1864).

Type: India. Assam, 1850, W. Griffith 1190 [Tetranthera n. 17, Herb. Hook. f. et Thoms.] (lectotype K-000793183!, here designated; isolectotype BM-000951039!).

Distribution: India, endemic (Arunachal Pradesh, Assam and Meghalaya).

Notes: In protologue of Tetranthera rangoonensis var. assamica, Meisner cited 'In Assam (Jenkins !)., Tetranthera 17. Hook. fil. et Thoms.! Hb. Ind. Or.' Three specimens belonging to the herbarium of Hooker f. \& Thomson, Tetranthera no. 17 are now extant, which comprised of a single specimen gathered by T.J. Jenkins s.n. (K-000357513) and two of W. Griffith 1190 (K000793183 and BM-000951039). Of these, K-000793183, is designated here as the lectotype as it agrees well with the protologue and also includes a short description of the flower by Hooker.

\footnotetext{
${ }^{1}$ Corresponding author. Email: kad_arti396@yahoo.com

${ }^{2}$ Botanical Survey of India, Head Quarter, CGO Complex, Salt Lake City, Kolkata 700 064, West Bengal, India.
} 
From the protologue, it seems that "Jenkins" and "Tetranthera 17. Hook. fil. et Thoms" are different collections and two of W. Griffith 1190 (K-000793183 and BM-000951039) likely belong to "Tetranthera 17. Hook. fil. et Thoms".

2. Litsea coriacea (B. Heyne ex Nees) Hook. f., Fl. Brit. India 5: 166 (1886). Tetranthera coriacea B. Heyne ex Nees in Wall., Pl. Asiat. Rar. 2: 66 (1831).

Type: India. Deccan Peninsula, s.d., B. Heyne s.n. [in Wallich Number. List no. 2556] (lectotype GZU-000254469!, here designated; isolectotype BM-000793685!).

Distribution: India, endemic (Goa, Karnataka, Kerala and Tamil Nadu).

Notes: Three specimens are extant, two at GZU (GZU-000254468 and GZU-000254469) and one at BM (BM-000793685). The GZU-000254469 specimen is designated here as the lectotype as it agrees well with the protologue.

3. Litsea membranifolia Hook. f., Fl. Brit. India 5: 159 (1886).

Type: India. Arunachal Pradesh, Dibang Valley, Mishmi Hills, s.d., W. Griffith s.n. [Kew Distrb. 4310] (lectotype K-000357530!, here designated; isolectotypes K-000793176!, GH00415039!).

Distribution: India, endemic (Arunachal Pradesh and Nagaland).

Notes: Hooker described Litsea membranifolia on the basis of specimens from 'Upper Assam; Mishmi Hills, and woods at Yen, Griffith (Kew Distrib. 4310)', but no specific specimen was indicated as the holotype. Furthermore, for this species, three specimens of Griffith's collections are extant, two at $\mathrm{K}$ (K-000357530 and K-000793176) and one at GH (GH-00415039). The K000357530 specimen is designated here as the lectotype as it agrees well with the protologue.

Ngernsaengsaruay et al. (2011: 72) cited the following: "Type: India, East Bengal, Griffith 4310 (holotype K!)". Although they cited K as housing the "holotype," their citation of "holotype" is not corrected to lectotype. Because, from 2001, an act of lecto-, neo-, and epitypification needs the citation of the phrase, "here designated" or its equivalent. The critical scrutiny of description provided in Ngernsaengsaruay et al. (l.c.) shows that it is best matches with L. glutinosa (Lour.) C.B. Rob., and thus the occurrence of this species in Thailand is uncertain and needs further confirmation based on fresh collections.

4. Litsea oleoides (Meisn.) Hook. f., Fl. Brit. India 5: 175 (1886). Tetranthera oleoides Meisn. in DC., Prodr. 15(1): 195 (1864).

Type: India. Kerala, Sispauray (Sispara), April 1846, R. Wight 2530 (lectotype K-000357533!, here designated).

Syntype: India. Kerala, s.d., R. Wight 54 (NY-00355989!).

Distribution: India, endemic (Kerala and Tamil Nadu).

Notes: Meisner described Tetranthera oleoides on the basis of specimen(s) from 'In Penins. Indiae Or.? (Wight!)'. The type data lack Wight's collection number and date, and information on the number of specimens used by Meisner to describe this species. Currently, Meisner's main herbarium is at New York (NY), which has one fragmentary specimen of this species (NY00355989); the specimen shows "Tetranthera oleoides Meisn. In Hb. Hook., "Wight. Hb. N. 54!" and an illegible writing of what seems to be the locality. In contrast, the $\mathrm{K}$ specimen (K000357533) is complete and fits well with the protologue. Therefore, the K-000357533 specimen is designated here as the lectotype as it agrees well with the protologue. 
5. Litsea stocksii (Meisn.) Hook. f., Fl. Brit. India 5: 176 (1886). Cylicodaphne oblonga Nees var. stocksii Meisn. in DC., Prodr. 15(1): 205 (1864).

Type: India. Canara (Karnataka), s.d., J.E. Stocks s.n. (lectotype K-000357539!, here designated; isolectotype K-000793237!).

Litsea stocksii (Meisn.) Hook. f. var. glabrescens (Meisn.) Hook. f., Fl. Brit. India 5: 176 (1886). Cylicodaphne wightiana Meisn. var. glabrescens Meisn. in DC., Prodr. 15(1): 201 (1864).

Type: India. Canara (Karnataka), s.d., J.E. Stocks s.n. (lectotype K-000793240!, here designated; isolectotype K-000357538!).

Litsea josephii S. M. Almeida, Fl. Savantwadi 1: 364 (1990), nom. illeg. et superfl. for $L$. stocksii

Litsea vartakii M. R. Almeida, J. Bombay Nat. Hist. Soc. 86(2): 180 (1989), nom. illeg. et superfl. for L. stocksii

Distribution: India, endemic (Goa, Karnataka, Kerala, Maharashtra and Tamil Nadu).

Notes: Hooker (l.c.) based his Litsea stocksii on Cylicodaphne oblonga var. stocksii Meisn.; at the same time, he also included "Tetranthera lancaefolia (sensu) Graham (Cat. Pl. Bombay. 174. 1839 , non Roxb. 1832)" with a query sign. Because of the doubtful inclusion, the citation does not cause superfluity to the name $L$. stocksii.

Meisner described Cylicodaphne oblonga var. stocksii on the basis of specimens from 'In Canara (Stocks!).' Two specimens collected by Stocks from Canara are now extant at K (K000357539 and $\mathrm{K}-000793237)$. The $\mathrm{K}-000357539$ specimen is designated here as the lectotype as it agrees well with the protologue.

Meisner described Cylicodaphne wightiana var. glabrescens Meisner on the basis of specimens from 'Wight!, Perrott. n. 451!, 452!, 1843!, Hohenack. n. 1335! Stocks! Gardn.! Law!', but no specific herbarium sheet was designated as the holotype. Pertaining to this specification, only two specimens collected by Stocks from Canara are now extant at K (K-000793240 and K000357538). The best one, K-000793240, is designated here as the lectotype as it agrees well with the protologue.

6. Litsea venulosa (Meisn.) Hook. f., Fl. Brit. India 5: 161 (1886). Tetranthera venulosa Meisn. in DC., Prodr. 15(1): 187 (1864).

Type: India. Peninsula Indiae Orientalis, s.d., R. Wight s.n. (lectotype K-000793184!, here designated).

Syntypes: India. Peninsula Indiae Orientalis, s.d., R. Wight 2532a (L-0037108!); Tamil Nadu, Courtallam, Sep 1835, R. Wight $710 b$ (L-0037109!); Penins. Ind. Or. (Peninsula Indiae Orientalis), s.d., R. Wight 30 (NY-00356000!).

Distribution: India, endemic (Kerala and Tamil Nadu).

Notes: Meisner described Tetranthera venulosa on the basis of specimens from 'In Penins.? Indiae (Wight!).' Four specimens belonging to Peninsula Indiae Orientalis of the Wight Herbarium are extant (K-000793184, L-0037108, L-0037109, and NY-00356000). The K000793184 specimen is designated here as the lectotype as it agrees well with the protologue.

7. Litsea wightiana (Nees) Hook. f., Fl. Brit. India 5: 177 (1886). Cylicodaphne wightiana Nees in Wall., Pl. Asiat. Rar. 2: 68 (1831).

Type: India. Peninsula Indiae Orientalis, s.d., R. Wight 2232 [= Wall. Cat. n. 2557 A] (lectotype P-02003106!, here designated; isolectotypes, BR-0000013053000!, K-000357542!). 
Distribution: India, endemic (Maharashtra, Goa, Karnataka, Kerala and Tamil Nadu).

Notes: In the protologue of Cylicodaphne wightiana, Nees cited 'Wall. Cat. n. 2557, A, B. Habitat in sylvis Nilghiry (Deenhutty in schedis). (E. Noton.) Vidi etiam in Hb. Wight.' The "Wall. Cat. n. 2557 A" specimen belongs to the Wight Herbarium, whereas the "Wall. Cat. n. 2557 B" specimen belongs to collections from Nilghiry by E. Noton. Three specimens belonging to the Wight herbarium (Wall. Cat. n. 2557 A) are extant (BR-0000013053000, K-000357542, and $\mathrm{P}-02003106)$. Of the choice of specimens, P-02003106! is designated here as the lectotype as it agrees well with the protologue.

\section{Types of three endemic species are also specified below as in their protologues no holotypes were cited.}

1. Litsea beddomei Hook. f., Fl. Brit. India. 5: 177 (1886).

Type: India. Tamil Nadu, Tinnevelly (Tirunelveli), Dec 1880, R.H. Beddome 15 (Lectotype, here designated (or perhaps holotype): K-000357515!).

Distribution: India, endemic (Kerala and Tamil Nadu).

Notes: For his new species Litsea beddomei, Hooker cited the type collection information as follows: "SOUTH DECCAN; Tinnevelly Hills, Beddome." The protologue lacks the collection date and number. Furthermore, neither a holotype nor the name of the herbarium housing the type was mentioned. A single specimen collected by Beddome from Tirunelveli in December 1880 bearing Hooker's annotation ' $L$. beddomei' is now extant at K (K-000357515). Because of the uncertainty whether Hooker's description was based on the $\mathrm{K}$ single specimen alone or on additional specimens, it is concluded here that the single specimen at $\mathrm{K}$ may serve as the holotype or a lectotype.

\section{Litsea mishmiensis Hook. f., Fl. Brit. India 5: 161 (1886).}

Type: India. Arunachal Pradesh, Dibang Valley, Laim-planj-thaya, Mishmi Hills, s.d., W. Griffith 4317 (Lectotype, here designated (or perhaps holotype): K-000357531!).

Distribution: India, endemic (Arunachal Pradesh).

Notes: Within the protologue of Litsea mishmiensis, Hooker mentioned the following: 'Upper Assam; Mishmi Hills at Laim-planj-thaya, Griffith'. The collection date and number were not cited. A single type specimen is now extant at K (K-000357531). Hooker, however, did not cite a holotype or mention the herbarium housing the type. It is uncertain whether Hooker's description was based on the $\mathrm{K}$ single specimen alone or on additional specimens. Therefore, it is concluded here that the single specimen at $\mathrm{K}$ may serve as the holotype or a lectotype.

3. Litsea oreophila Hook. f., Fl. Brit. India 5: 156 (1886). Lindera hookeri Meisn. in DC., Prodr. 15(1): 245 (1864).

Type: India. Sikkim, Lachoong (Lachung), 10,000-11,000 ft., 29 Aug 1849, J.D. Hooker s.n. [Tetranthera n. 4, Herb. Hook. f. et Thoms.] (holotype K-000357534!).

Distribution: India, endemic (Sikkim).

Notes: Within the protologue of Lindera hookeri, Meisner mentioned: 'In Sikkim (Hook. fil. et Thoms. hb. Ind. or. Tetranthera 4!)' and "(v. s. in hb. Hook.)" (= vidi siccam in Hooker herbarium $(\mathrm{K})$ ]. Only one specimen is extant at $\mathrm{K}$ (K-000357534), which is therefore the obligatory holotype. 


\section{Acknowledgements}

The authors are grateful to the curators of BM, BR, GH, GZU, K, L, NY and P herbaria for information and images of type specimens. We gratefully acknowledge late Prof. James L. Reveal, Cornell University, Ithaca, USA for his critical comments and suggestions on the manuscript.

\section{References}

Bhuinya, T., Singh, P. and Mukherjee, S.K. 2010. An account of the species of Litsea Lam. (Lauraceae) endemic to India. Bangladesh J. Pl. Taxon. 17(2): 183-191.

Mabberley, D.J. 2008. Mabberley's Plant-Book: A portable dictionary of plants, their classification and uses. $3^{\text {rd }}$ edition. Cambridge University Press, Cambridge, $1020 \mathrm{pp}$.

McNeill, J., Barrie, F.R., Buck, W.R., Demoulin, V., Greuter, W., Hawksworth, D.L., Herendeen, P.S., Knapp, S., Marhold, K., Prado, J., Proud'homme van Reine, W.F., Smith, G.F., Wiersema, J.H. and Turland, N.J. (Eds) 2012. International Code of Nomenclature for algae, fungi and plants (Melbourne Code): Adopted by the Eighteenth International Botanical Congress, Melbourne, Australia, July 2011. Regnum Vegetabile 154: 1-274.

Ngernsaengsaruay, C., Middleton, D.J. and Chayamariat, K. 2011. A revision of the genus Litsea Lam. (Lauraceae) in Thailand. Thai Forest Bull. Bot. 39: 40-119.

Singh, R.K. 2015. Typification of seven species of Litsea (Lauraceae) endemic to India. Phytotaxa 201(4): 278-286.

(Manuscript received on 12 January 2015; revised on 17 July 2015) 